\title{
Corneal ulcer: a retrospective study of a cases seen at the Hospital das Clínicas, Federal University of Espirito Santo
}

\author{
Úlcera de córnea: estudo retrospectivo de casos atendidos no \\ Hospital das Clínicas da Universidade Federal do Espírito Santo
}

Júlia Dutra Comarella ${ }^{1}$ Patricia Grativol Costa Saraiva², Fábio Petersen Saraiva ${ }^{3}$

\begin{abstract}
Objetive: To identify the major etiological agents of UC in the main referral center for this disease in the state of Espírito Santo (Hospital Universitario Cassiano Antonio de Moraes - HUCAM). Methods: This is a retrospective study of UC cases that underwent microbiological analysis from january 2009 to june 2013 at HUCAM. Results: Three hundred ninety-eight cases were studied. Microbiological cultures were positive in $60 \%$ and negative in $40 \%$ of cases. The Gram stain was positive in $28 \%$, negative in $61 \%$ and was not performed in $11 \%$.Among the total number of tests, $16.3 \%$ were classified as insufficient material for analysis. The microbiological examination, including gram stain and culture, was positive in 250 tests $(62.8 \%)$. It was identified bacteria in $48 \%$, fungi in $17.6 \%$ and protozoa in $0,8 \%$ of cases. Conclusion: The study identified the main etiological agents involved in the UC at HUCAM. Hence, it provides data that can help physicians to do a better presumptive diagnosis and a more appropirate initial empirical treatment when indicated. Gram positive bacteria and filamentous fungi have a prominent role in the etiology of UC in ES.
\end{abstract}

Keywords: Corneal ulcer; Eye infections

\section{RESUMO}

Objetivo: Identificar os principais agentes etiológicos das úlceras de córnea atendidas no principal centro de referência para esta moléstia no estado do Espírito Santo (Hospital Universitário Cassiano Antônio de Moraes - HUCAM). Métodos: Estudo retrospectivo de prontuários, identificados por meio dos registros do laboratório de microbiologia do HUCAM, dos casos de úlcera de córnea submetidos à coleta de material para análise microbiológica no período de janeiro de 2009 a junho de 2013. Resultados: Dos 398 casos foram estudados e o resultado da cultura foi positivo em $60 \%$ e negativo em $40 \%$ dos casos. A bacterioscopia foi positiva em $28 \%$, negativa em $61 \%$ e não foi realizada em 11\%. Dentre o total de exames, 16,3\% foram classificados como material insuficiente para análise. O exame microbiológico, incluindo bacterioscopia e cultura, foi positivo em 250 exames (62,8\%), sendo identificado bactérias em $48 \%$ dos casos, fungos em 17,6\% e protozoários em 0,8\%. Conclusão: Este trabalho identificou os principais agentes etiológicos envolvidos na UC atendidas no HUCAM. Desta forma, fornecemos subsídios para um melhor o diagnóstico presuntivo e condução mais apropriada do tratamento empírico inicial, quando indicado. As bactérias Gram-positivas e fungos filamentosos apresentam papel de destaque na etiologia das UC no ES.

Descritores: Úlcera da córnea; infecções oculares

\footnotetext{
${ }^{1}$ Department of Ophthalmology, University Hospital, Federal University of Espírito Santo, Vitória / ES, Brazil.

${ }^{2}$ Medical School of Empresa Brasileira de Ensino, Pesquisa e Extensão A.S. - Multivix, Vitória / ES, Brazil.

${ }^{3}$ Department of Specialist Medicine, Federal University of Espírito Santo, Vitória/ES, Brazil.
}

Work conducted at the University Hospital of the Federal University of Espírito Santo, Vitória / ES, Brazil.

The authors declare no conflict of interest.

Received for publication 25/07/2014 - Accpted for publication 04/11/2014 


\section{INTRODUCTION}

I nfectious corneal ulcer (ICU) or infectious keratitis is an ophthalmic emergency. It involves a loss of integrity of the corneal epithelium with infiltration of the underlying stroma by leukocytes, which are associated with inflammation. Corneal injury is caused both by the aetiological agent (fungi, bacteria, virus, or protozoa) and by immune mechanisms.

Although studies comparing the aetiology and incidence of ICUs are still limited, important variations are known to occur across continents, countries and regions ${ }^{1-3}$. The epidemiology of ICUs is not well determined because most data come from referral hospitals, therefore results may not be representative of the general population. In developing countries, 1.5 to 2 million ulcers are estimated to occur every year ${ }^{2}$, resulting in a large number of corneal opacities, which in turn represent the second leading cause of preventable blindness in certain tropical countries ${ }^{1}$.

The infectious agent is identified through microbiological analysis of a sample of the lesion ${ }^{1}$, which should always include a culture with antibiogram. However, empirical treatment with broad-spectrum topical antibiotics - based on medical history and the clinical characteristics of the lesion - must often be initiated early to control the infectious process. Prior knowledge of the epidemiological profile of infectious ulcers in the region can be very useful for choosing the type of empirical treatment. Around the world, 232 species of microorganisms that cause ICUs have been identified ${ }^{2}$. Therefore, microbiological analysis in referral hospitals is critical to identify the most prevalent aetiological agents in the region and to provide important information on their sensitivity to existing antibiotics ${ }^{4}$.

The aim of this study was to evaluate the epidemiology of infectious ulcers at Cassiano Antônio de Moraes University Hospital (HUCAM) in order to assist physicians in the clinical management of cases in the region.

\section{Methods}

HUCAM is a referral centre in the State of Espírito Santo (ES) for aetiological diagnosis and treatment of corneal ulcers. Patients treated at HUCAM come from all across ES and even from neighbouring states such as Bahia and Minas Gerais. Its staff has broad experience treating corneal ulcers, and the hospital also has a microbiological laboratory and an eye bank for the treatment of complicated cases that require corneal transplantation.

This was a retrospective study of all corneal ulcers submitted to microbiological analysis at HUCAM between January 2009 and June 2013. Data were obtained from the records of HUCAM's Laboratory of Microbiology. All cases described as corneal ulcers were included, totalling 398 patients. The materials was sampled according to the Department of Ophthalmology's protocol, which includes: discontinuing the use of air conditioning in the room; topical anaesthesia with instillation of hydrochloride benoxinate $0.4 \%$; placing a blepharostat; collecting material from the margin and floor of the ulcer using a Kimura spatula under slit lamp examination; preparing two slides for bacterioscopy with Gram staining; and culture in BHI (Brain Heart Infusion), blood agar, chocolate agar, and Sabouraud agar.

\section{Results}

Of the 398 patients included in the study, 264 (66.4\%) were male and 134 (33.6\%) were female. Culture results were positive in $60 \%$ of cases and negative in $40 \%$. Bacterioscopy was positive in $28 \%$ of cases, negative in $61 \%$, and was not performed in $11 \%$. In $16.3 \%$ of cases there was insufficient material for analysis. This percentage was $63.6 \%$ in the group that did not undergo bacterioscopy, which partially explains why the test was not performed.

Microbiological examination, including bacterioscopy and culture, yielded 250 positive results $(62.8 \%)$, with bacteria being identified in $48 \%$ of the cases, fungi in $17.6 \%$ and protozoans in $0.8 \%$. Final results are distributed as shown in Table 1 .

Table 1

Results from microbiological analysis of infectious corneal ulcers.

\begin{tabular}{lcc}
\hline Infectious agent & Number of cases & \% \\
\hline Flamentous fungi & 67 & 16.8 \\
Gram negative bacteria & 87 & 21.9 \\
Gram positive bacteria & 104 & 26.1 \\
Yeasts & 3 & 0.8 \\
Negative & 148 & 37.2 \\
\hline
\end{tabular}

A greater number of fungal ulcers was identified in the months of June (nine cases) and December (10 cases). In the remaining months, the number of cases ranged from two to six, as shown in Chart 1.

\section{Chart 1}

\section{Distribution of fungal ulcers over the year, from January 2009 to December 2012.}

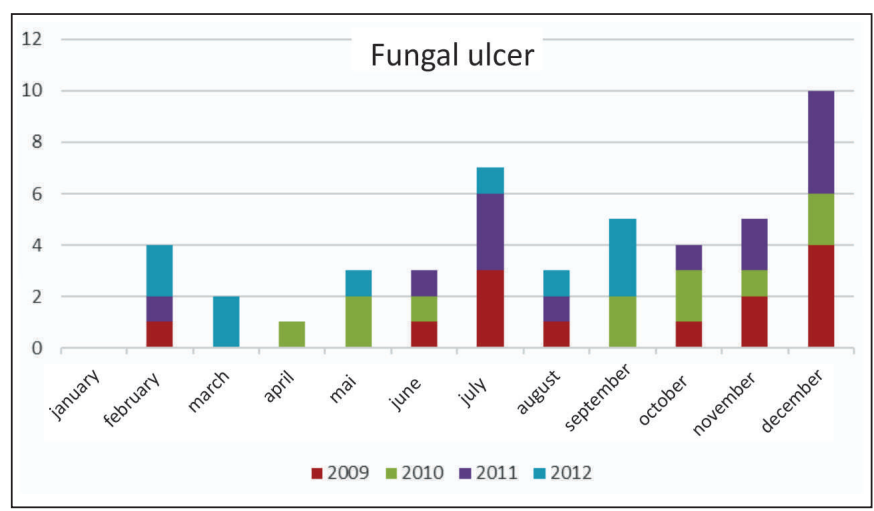

Table 2 shows the species of microorganisms found in this study.

\section{Discussion}

Around the world, infectious keratitis is a major cause of morbidity and low visual acuity due to corneal opacity, ocular perforation, and endophthalmitis ${ }^{1-3,5,6}$. The severity of the disease depends on the aggressiveness of the agent, as well as adherence 
Table 2

Microorganisms found during microbiological analysis of infectious corneal ulcers

\begin{tabular}{|c|c|c|c|}
\hline Species & Number of cases & Species & Number of cases \\
\hline Achantamoeba & 2 & Proteus mirabilis & 1 \\
\hline Acinetobacter baumannii & 2 & Pseudomonas aeruginosa & 45 \\
\hline Bacillus spp & 1 & Pseudomonas stutzeri & 1 \\
\hline Bacilo Gram-negativo & 13 & Raoultella ornithinolytica & 1 \\
\hline Bacilo Gram-positivo & 5 & Rizhopus spp & 3 \\
\hline Candida spp & 2 & Serratia marcescens & 9 \\
\hline Cephalosporium sp & 1 & Shewanella algae & 1 \\
\hline Citrobacter koseri & 2 & Staphylococcus aureus & 21 \\
\hline Cocos Gram-positivos & 3 & Staphylococcus auricularis & 1 \\
\hline Curvularia spp & 1 & Staphylococcus capitis & 2 \\
\hline Diplococos Gram-negativos & 1 & Staphylococcus coagulase negativa & 4 \\
\hline Klebsiella pneumoniae & 1 & Streptococcus & 1 \\
\hline Kocuria kristinae & 2 & Streptococcus agalactiae & 1 \\
\hline Micrococcus spp & 1 & Streptococcus mitis & 3 \\
\hline Moraxella group- & 2 & Streptococcus pneumoniae & 18 \\
\hline Morganella morganii & 2 & Streptococcus viridans & 8 \\
\hline Mucor spp & 1 & Trichosporon spp & 1 \\
\hline Neisseria spp & 2 & Trichosporum asabii & 1 \\
\hline Nocardia & 1 & Total & 263 \\
\hline
\end{tabular}

to treatment and how soon the therapy is started. Delays in treatment are generally associated with limited access to specialist care, which is common in developing countries ${ }^{2,7}$.

The failure to provide early specific treatment against ICU can trigger severe ocular complications such as descemetocele, perforation, and endophthalmitis. Correct identification of the aetiological agent is extremely important for selecting the specific treatment for each case. Therefore, assessing the epidemiology and seasonal variation of ICUs can help ophthalmologists determine the most likely agent and select the initial therapeutic method when microbiological analysis is not available or while waiting for culture results.

In this study, an average of 7.5 corneal ulcers were treated per month, with a predominance of male patients $(66.3 \%$, vs. $33.7 \%$ female), similar to other studies in literature ${ }^{8,9}$. For example, Sacramento et al. (2005) studied 132 patients with ICUs, of which $59.1 \%$ were male and $40.9 \%$ were female. Similarly, Saha et al. (2009) studied 74 patients, of which $65 \%$ were male and $35 \%$ were female ${ }^{8,9}$. This is probably due to fact that men are more exposed to eye injuries than women, especially rural workers ${ }^{9}$. A study in Philadelphia found a greater proportion of women with eye injuries $(58.3 \%)$, although the sample size was smaller (24 cases) ${ }^{10}$. In Nepal, the proportion of male and female individuals with ICUs was similar ${ }^{1}$.

In the present study, microbiological examination was positive in $62.8 \%$ of cases, which is not ideal, although higher than in previous Brazilian (28.86 to $65 \%)^{8,12}$ and international (40 to $80 \%$ ) studies ${ }^{11-16}$. The distribution of aetiological agents was in contrast with the literature. Among positive results, bacteria were identified in 191 (76.4\%) cases (104 Gram-positive and 87 Gram-negative bacteria), fungi in 70 (28\%) (of which only three were yeasts), and bacteria and protozoa in two cases $(0.8 \%)$. On the other hand, in a study conducted in Sorocaba, Brazil, Rocha et al. (2011) found bacteria in $95.33 \%$ of cases (73.23\% Gram-positive and $26.77 \%$ Gram-negative) and fungi in only $4.67 \%^{12}$. In São Paulo, Sacramento et al. (2005) found bacteria in $70.9 \%$ (51.1\% Gram-positive cocci, $34.9 \%$ Gramnegative cocci, and $6.9 \%$ Gram-positive bacilli), protozoa in $16.3 \%$ and fungi in $12.8 \%^{8}$. In India, only 23.4 to $32.77 \%$ of ICUs are caused exclusively by bacteria, 26.43 to $34.4 \%$ by fungi, 1.04 to $1.4 \%$ by protozoa with or without bacteria, and $23.4 \%$ by microsporidia with or without bacteria ${ }^{14,16}$. In Nepal, bacteria are responsible for $63.2 \%$ of cases and fungi for $6.7 \%{ }^{11}$.

There are differences in the national and international literature regarding the distribution of species, not only in comparison with our results, but also between other studies. These differences are probably due to the climate, environment, predominant economic activity and exposure to risk factors, especially trauma and the use of contact lenses ${ }^{1-3,12}$. These factors explain why developing countries, many of which have tropical climates and agriculture-based economies, present a higher percentage of fungal ulcers, in contrast with developed countries, where ulcers related to contact lenses are more common ${ }^{1-3}$. In fact, climate and geographic location are believed to be associated with the clinical presentation and progression of ulcers, especially in the case of fungi ${ }^{2}$. The most commonly isolated species in our 
study were: Pseudomonas aeruginosa (18\%), Fusarium spp. (17.2\%), Staphylococcus epidermidis (9.6\%), Staphylococcus aureus (8.4\%), Streptococcus pneumoniae (7.2\%), and Serratia marcescens $(3.6 \%)$. The main species isolated in a study in Sorocaba were S. aureus, S. epidermidis (30.56\% each), Streptococcus sp. and Pseudomonas sp. $(9.43 \% \text { each })^{12}$. In the city of São Paulo, the most frequent bacteria were coagulasenegative staphylococci (30.2\%), Acanthamoeba sp. (16.3\%), Pseudomonas sp. and S. pneumoniae (11.6\% each) ${ }^{8}$. These results underline the significant variation between national studies.

There are also great differences in international literature concerning the aetiology of ICUs, with S. epidermidis, S. pneumonia, and $P$. aeruginosa being the bacteria most commonly isolated $^{2}$. In Nepal, bacteria accounted for $63.2 \%$ and fungi for $6.7 \%$ of cases. Also in Nepal, Upadhyay et al. found S. pneumoniae in $31.1 \%$ of positive cultures, followed by $S$. epidermidis, S. aureus, and Pseudomonas sp. ${ }^{11}$. In the United States, Wahl et al. found $S$. epidermidis and S. aureus as the major aetiological agents $(28 \%$ and $16 \%$, respectively $)^{17}$.

In our study, fungal ulcers accounted for $17.6 \%$ (70) of cases, with Fusarium spp. and Aspergillus spp. being the most commonly isolated species $(17.2 \%$ and $1.6 \%$ of positive cases, respectively). In Sorocaba, Fusarium solani was the most common fungus ${ }^{8}$. Despite the high incidence of fungal ulcers in the state of Espirito Santo, it is still below the values found in India (38.06 to $44 \%)$, Bangladesh (36\%), Ghana (37.6\%) and southern Florida $(35 \%)^{1,9}$. Our study is in agreement with the international literature as regards the species of fungi found, with filamentous fungi, especially Fusarium spp. and Aspergillus spp., being the most common $^{1,2,14,18}$. In India and Nepal, however, different results were found, with Aspergillus spp. being the most common followed by $C$. albicans, while Fusarium sp. was only the third most common fungal agent ${ }^{9,11}$. Also in India, Gopinathan et al. (2002) found Curvularia as the most common fungal agent ${ }^{19}$. In certain countries, yeasts account for the largest number fungal ICUs. For example, in Victoria, Australia, C. albicans was the most common agent (37.2\%), followed by Aspergillus fumigatus $(17.1 \%)$ and Fusarium sp. $(14.3 \%)^{20}$. In Pennsylvania, United States, C. albicans $(45.8 \%)$ was also found more frequently than Fusarium sp. $(25 \%)^{10}$.

In our study, fungal ulcers occurred predominantly in the months of June and December. The higher incidence in June may be due to the fact that the state is a large coffee producer, whose harvest begins in early June. During this time of year, rural workers, who are mostly male, are exposed to eye injuries caused by certain parts of the plant ${ }^{9}$. The higher incidence in December is possibly a result of patient referrals from other clinics and municipalities that discontinue or reduce patient admissions during the holiday season. In India, a higher incidence of fungal ulcers was also documented in the monsoon season and in winter compared to the summer ${ }^{19}$.

\section{Conclusion}

EThis study identified the main aetiological agents of ICUs treated at HUCAM, the referral hospital in the state Espírito Santo for this condition. These results can help physicians perform a better presumptive diagnosis and a more appropriate empirical treatment when indicated. Gram-positive bacteria and filamentous fungi play a significant role in the aetiology of ICUs in the state of Espírito Santo.

\section{ReFERENCES}

1. Leck AK, Thomas PA, Hagan M, Kaliamurthy J, Ackuaku E, John $\mathrm{M}$, et al. Aetiology of suppurative corneal ulcers in Ghana and south India, and epidemiology of fungal keratitis. Br J Ophthalmol. 2002;86(11):1211-5.

2. Karsten E, Watson SL, Foster LJ. Diversity of Microbial Species Implicated in Keratitis: A Review. Open Ophthalmol J. 2012;6: 110-24.

3. Shah A, Sachdev A, Coggon D, Hossain P. Geographic Variations in Microbial Keratitis: An analysis of the Peer-Reviewed Literature. Br J Ophthalmol. 2011;95(6):762-7.

4. CBO - Conselho Brasileiro de Oftalmologia; Coleção CBO: Série Oftalmologia Brasileira. São Paulo: Guanabara; 2013.

5. Mattos FB, Agostini FS, Mattos MB, Batista DMP. Úlcera de córnea por Pseudomonas stutzeri. Rev Bras Oftalmol. 2012;71(2):111-4.

6. Zeschau A, Balestrin IG, Stock RA, Bonamigo EL. Indicações de ceratoplastia: estudo retrospectivo em um Hospital Universitário. Rev Bras Oftalmol. 2013;72(5):316-20.

7. Kara-Junior N, Zanato MC, Vilaca V, Kara-José N. Aspectos médicos e sociais no atendimento oftalmológico de urgência. Arq Bras Oftalmol. 2001; 64(1):39-43.

8. Sacramento RS, Castro L, Freitas D, Branco BC, Lima ALH, Vieira L, et al. Estudo dos fatores epidemiológicos e influentes na ceratite microbiana em serviço universitário. Rev Bras Oftalmol. 2005;64(1):7-13.

9. Saha S, Banerjee D, Khetan A, Sengupta J. Epidemiological profile of fungal keratitis in urban population of West Bengal, India. Oman J Ophthalmol. 2009;2(3):114-8.

10. Tanure MA, Cohen EJ, Sudesh S, Rapuano CJ, Laibson PR. Spectrum of fungal keratitis at Wills Eye Hospital, Philadelphia, Pennsylvania. Cornea. 2000;19(3):307-12.

11. Upadhyay MP, Karmacharya PC, Koirala S, Tuladhar NR, Bryan LE, Smolin G, et al. Epidemiologic characteristics, predisposing factors, and etiologic diagnosis of corneal ulceration in Nepal. Am J Ophthalmol. 1991;111(1):92-9.

12. Rocha GAN, Silva RF, Lopes MF, Pereira NC, Sousa LB. Principais patógenos e susceptibilidade in vitro antimicrobiana em ceratites bacterianas: Revisão de cinco anos, 2005 a 2009. Arq Bras Oftalmol. 2011;74(1):28-32.

13. McLeod SD, Kolahdouz-Isfahani A, Rostamian K, Flowers CW, Lee PP, McDonnell PJ. The role of smears, cultures, and antibiotic sensitivity testing in the management of suspected infectious keratitis. Ophthalmology. 1996;103(1):23-8.

14. Rautaraya B, Sharma S, Kar S, Das S, Sahu SK. Diagnosis and treatment outcome of mycotic keratitis at a tertiary eye care center in eastern India. BMC Ophthalmol. 2011;11:39.

15. Levey SB, Katz HR, Abrams DA, Hirschbein MJ, Marsh MJ. The role of cultures in the management of ulcerative keratitis. Cornea. 1997;16(4):383-6.

16. Bharathi MJ, Ramakrishnan R, Meenakshi R, Padmavathy S, Shivakumar C, Srinivasan M. Microbial keratitis in South India: influence of risk factors, climate, and geographical variation. Ophthalmic Epidemiol. 2007;14(2):61-9.

17. Wahl JC, Katz HR, Abrams DA. Infectious keratitis in Baltimore. Ann Ophthalmol. 1991;23(6):234-7.

18. Thomas PA. Fungal infections of the cornea. Eye. 2003;17(8):85262. 
19. Gopinathan U, Garg P, Fernandes M, Sharma S, Athmanathan S, Rao GN. The epidemiological features and laboratory results of fungal keratitis: a 10-year review at a referral eye care center in South India. Cornea. 2002;21(6):555-9.

20. Bhartiya P, Daniell M, Constantinou M, Islam FM, Taylor HR. Fungal keratitis in Melbourne. Clin Experiment Ophthalmol. 2007;35(2):124-30.

\section{Corresponding author:}

Fábio Petersen Saraiva

Departamento de Medicina Especializada/CCS/UFES

Av. Marechal Campos, 1468, Maruípe, Vitória/ES, Brazil CEP: 29047-105

E-mail: fabiopetersen@yahoo.com.br 